\title{
Timing of larval release by two Caribbean demosponges
}

\author{
Niels Lindquist ${ }^{1, *}$, Robin Bolser $^{1}$, Katie Laing ${ }^{2}$ \\ 'University of North Carolina at Chapel Hill, Institute of Marine Sciences, 3431 Arendell Street, Morehead City, \\ North Carolina 28557, USA \\ ${ }^{2}$ NOAA National Undersea Research Center, University of North Carolina at Wilmington, 7205 Wrightsville Avenue, \\ Wilmington, North Carolina 28403, USA
}

\begin{abstract}
The timing of larval release has important implications for a larva's potential vulnerability to predators and environmental stresses. For larvae with planktonic periods of only minutes to hours, timing of larval release also determines the light levels that larvae experience, which can strongly influence their settlement behavior We placed larval traps over colonies of 2 common Caribbean sponges and found that both species released larvae during daylight hours. Niphates digitalis generally releases its larvae between $07: 00$ and 11:00 h, while Callyspongia vaginalis releases its larvae later in the day. Of 17 captured $N$ digitalis larvae released 0.5 to $1 \mathrm{~m}$ above the substrate, 13 remained near the bottom, and 8 of these 13 contacted the substrate within $10 \mathrm{~min}$. For shorllived larvae, daytime release and their photonegative behavlor at settlement should drive them to settle in shaded microhabitats that protect juveniles from predators and solar U radiation. Larvae of $N$. digitalıs and $C$. vaginalis are distasteful to potential predators; thus they can remain near the bottom with fishes and yet not be consumed. These data support a general co-occurrence of daytime spawning of conspicuous, short-hind larvae and larval distastefulness that previously had been noted only for tropical ascidians.
\end{abstract}

KEY WORDS: Sponges Larvae. Timıng of larval release Larval dispersal Larval paiatability

Predation by fishes is thought to have strongly influenced the evolution of larval morphological characteristics and behaviors among benthic invertebrates, as well as adult spawning patterns (reviewed by Strathmann 1985, Young \& Chia 1989, Rumrill 1990, Morgan 1995a). Nighttime spawning is one means to diminish the morlality of vulnerable eggs and larvae by allowing them to disperse away from areas of high fish abundance under the cover of darkness. Nocturnal spawning is common among many groups of marine invertebrates, such as crustaceans (Morgan 1995b) and scleractinian corals (Babcock et al. 1986). In contrast, colonial ascidians release their larvae during daylight hours (reviewed by Svane \& Young 1989), and

-E-mail nlindquist@unc.edu these larvae typically disperse only a short distance before settling (van Duyl et al. 1981, Grosberg \& Quinn 1986, Olson \& McPherson 1987, Davis \& Butler 1989. Stoner 1990, Bingham \& Young 1991). The risk of predation for conspicuous, day-active ascidian larvae is low because they commonly are distasteful to fishes and can survive repeated 'sampling' attacks by fishes (Young \& Bingham 1987, Lindquist et al. 1992). Daytime spawning and settlement allows larvae of colonial ascidians to choose settlement sites when strong photic cues and their photonegative behavior at settlement (Svane \& Young 1989) drive them toward shaded microhabitats such as crevices and overhangs. Settlement in such sites diminishes juvenile mortality from large mobile predators, exposure to solar UV radiation, and other physical stresses (Keough \& Downes 1982 , Olson 1983, Young \& Chia 1984)

Lindquist \& Hay (1996) found that the conspicuous larvae of many Caribbean reef sponges, like those of tropical colonial ascidians, are distasteful to small predatory reef fishes. Thus, sponges might also be capable of exploiting the advantages of daytime larval release and settlement. Several lab-based studies have found (1) that brooded sponge larvae are released during daylight hours (Amano 1986, 1988, Lindquist \& Hay 1996), and (2) that sponge larvae are competent to settle within minutes to hours of their release from the adult (Ilan \& Loya 1988, 1990, Woollacott. 1993, Meroz \& Ilan 1995, Lindquist pers. obs.). Like larvae of colonial ascidians (van Duyl et al. 1981, Olson 1983), in situ swimming periods of sponge larvae may be considerably shorter than their swimming durations under laboratory conditions

To obtain field evidence on the relationship between palatability and timing of release for conspicuous larvae, we documented the timing of larval release for 2 common Caribbean sponges, Callyspongia vaginalis (Lamarck) and Niphates digitalis (Lamarck). Larvae of 
both species are distasteful to co-occurring fishes and corals (Lindquist 1996, Lindquist \& Hay 1996). Additionally, for $N$ digitalis, we observed larvae after their release to determine the length of the larval swimming period and if these larvae disperse near the bottom, where they would be exposed to large numbers of reef-associated predators, or if they moved toward the surface, away from the reef.

Methods. Niphates digitalis grows as a single erect tube that is gray to light purple in color. The tube is commonly 5 to $13 \mathrm{~cm}$ in diameter and has a wall thickness of 0.5 to $1 \mathrm{~cm}$. Callyspongia vaginalis commonly grows as clusters of erect tubes that are 3 to $8 \mathrm{~cm}$ in diameter with walls 0.5 to $1 \mathrm{~cm}$ thick. In the Florida Keys, USA, colonies of these sponges contain larvae from at least June through October (Lindquist pers. obs.). The larvae are released into the interior of the tube then expelled with the excurrent flow. Their larvae are brooded to an advanced stage in brooding chambers as has been noted for sponges in the Red Sea (Ilan \& Loya 1988, 1990) and on the Great Barrier Reef (Fromont 1994). Larvae of $N$. digitalis and $C$. vaginalis are 1 to 2 and 0.5 to $1 \mathrm{~mm}$ in length, respectively, and commonly gray colored.

The divers (aquanauts) who conducted the experiments described below were stationed for $10 \mathrm{~d}$ (July 23 to August 1,1994 ) in the NOAA-NURC undersea laboratory 'Aquarius' 'Aquarius' rests in 20 m of water on Conch Reef $\left(24^{\circ} 51^{\prime} \mathrm{N}, 8^{\circ} 28^{\prime} \mathrm{W}\right)$ near Key Largo. Florida. Aquanauts conducted 2 excursions each day. The morning excursion typically began between 06:00 and 08:00 h and lasted 4 to $5 \mathrm{~h}$. Because a minimum $5 \mathrm{~h}$ stay in 'Aquarius' is required between daily excursions, the second excursion typically began at 17:00 h and lasted 2 to $3 \mathrm{~h}$.

Larvae released by the sponges were trapped by covering the end of the sponge tube with a fine-mesh net. Each net was fitted with a buoyant receptacle that larvae could enter but not escape (Fig. 1). Larval traps were attached by stretching the free end of the net over the upper portion of the sponge tube. The slightly rough surface of the sponges securely held the larval traps in place with no apparent damage to the sponges. Larvae would occasionally become lodged between the netting and the exterior side of the sponge; these larvae still could be readily counted. Traps were checked for larvae each morning and evening. After counting trapped larvae, or on some days simply checking for the presence of larvae, each trap was removed from the sponge, cleaned of larvae, and then replaced. The traps were on the sponges for 1 to $6 \mathrm{~d}$. All sponges appeared healthy throughout the duration of our experiments.

To determine the time of day that Niphates digitalis releases its larvae, the aquanauts netted 15 individual

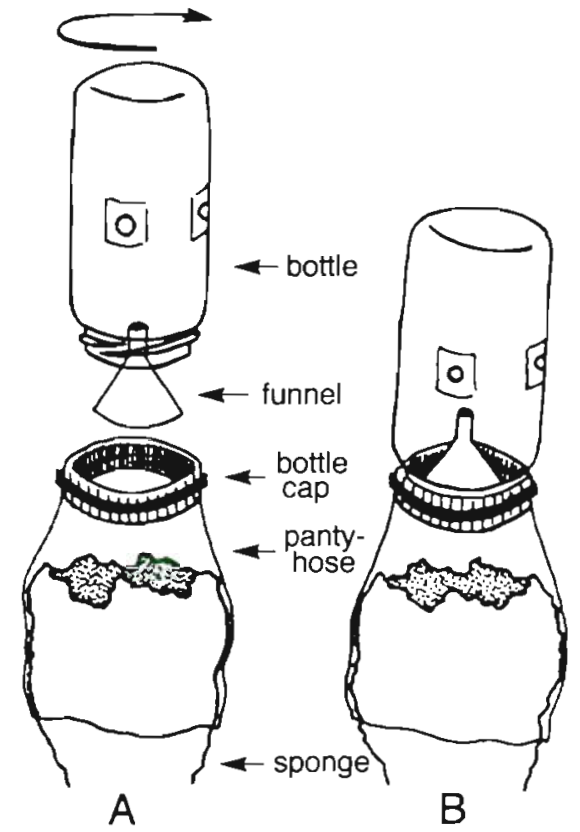

Fig. 1 Illustration of (A) the component parts of the larval traps and $(B)$ the fully assembled trap. Traps were made by securing the cap of a $200 \mathrm{ml}$ Nalgene bottle to the end of a 10 to $15 \mathrm{~cm}$ section of pantyhose. A $2.6 \mathrm{~cm}$ diameter hole was drilled through the center of the bottle cap so that when a small plastic funnel was placed on the cap, pointed upward into the attached bottle, larvae entering the bottle could not escape. We used clear Nalgene bottles so that larvae in the bottles could be easily seen. Four $1 \mathrm{~cm}$ diameter holes on the side of each bottle were covered with $200 \mu \mathrm{m} \mathrm{NiTEX}$ cloth to allow fresh seawater to areate the bottles

$N$. digitalis colonies in 17 to $23 \mathrm{~m}$ of water near 'Aquarius' During the late-afternoon excursion on July 23, larval traps were placed on 12 separate colonies. On July 27, traps were placed over an additional 4. colonies. We removed the trap from one of the original 12 netted colonies because this small colony had not released any larvae during the previous $72 \mathrm{~h}$. During the $6 \mathrm{~d}$ period beginning July 24, the presence of larvae in the traps was monitored daily. Between July 24 and 27 , release of larvae had already commenced by the time the aquanauts first arrived on site, so the traps were merely cleaned of larvae during the late-afternoon excursion. On July 28 , after rough seas delayed the aquanauts' departure from 'Aquarius', larvae in each trap were counted at the end of the morning excursion $(11: 30 \mathrm{~h})$ to record the number of larvae released since 17:00 h the previous day (i.e. when the traps were last cleaned of larvae). A second count was made at the beginning of the late-afternoon excursion to find the number of larvae released since the end of the morning excursion. On July 29, the early departure of the aquanauts allowed them to be on site before larval release had begun. At 4 times during this morning's 
excursion, the aquanauts counted the number of larvae in each trap, cleared the trap, and re-netted the sponge. One final count of larvae was made when the divers arrived on site for the afternoon excursion.

The aquanauts placed larval traps over 1 tube of individual Callyspongia raginalis colonies on July 26 ( 7 sponges netted), July 29 ( 7 sponges netted) and July 30 (1 sponge netted at 07:35 h). Between July 26 and 29, the traps were cleared of larvae each afternoon. On July 30, larvae in these traps were counted at 3 times during the morning excursion beginning at 06:42 h. A final count of released larvae was made at the beginning of the late-afternoon excursion.

To determine if larvae of Niphates digitalis move away from the reef after adults release them, 17 captured larvae were released individually 0.5 to $1 \mathrm{~m}$ above the substrate and followed from a distance of $1 \mathrm{~m}$ until each larva: (1) contacted the substrate, (2) swam or floated above the aquanauts' $15 \mathrm{~m}$ upperdepth limit, (3) traveled $>20 \mathrm{~m}$ from the point of release, or (4) remained in place in the water column for $>10$ min. Larval release experiments were conducted on the morning excursion of July 27 between 09:00 and 12:00 h. All larvae were motile and appeared healthy at the time of their release. Larvae of Callyspongia vaginalis were too small for the aquanauts to reliably follow under field conditions.

Results. Between July 24 and 27 most of the netted Niphates digitalis colonies had already released larvae by the time the aquanauts reached the study site. On these same days, no larvae were found in the traps at the beginning of the aquanauts' second excursion; thus $N$. digitalis did not release larvae between the time the traps were cleaned at the end of the first excursion and the beginning of the late-afternoon excursion. By $08: 48$ h on July 28,14 of 15 colonies had released larvae; the mean number of larvae released per colony was $28.3 \pm 6.4$ ( $\pm 1 \mathrm{SE}$ ) for the $18.5 \mathrm{~h}$ period ending at 11:30 h. At the beginning of the late-afternoon excursion on July 28 , the mean number of larvae found in the traps was $1.0 \pm 0.5( \pm 1 \mathrm{SE})$.

The early arrival of the aquanauts at the study site on July 29 allowed us to distinguish between night and early morning larval release by Niphates digitalis. By 06:30 h, only 2 larvae had been released by Colony 5; none of the remaining 14 colonies had released larvae (Table 1). Over the next 33 min, 3 additional sponges had released a few ( 2 to 5 ) larvae, and Colony 6 had released 65 larvae. The third observation period lasted 2 h 50 min because there were many larvae to count; 8 colonies had released 21 to 52 larvae, and 3 colonies had released 93 to 150 larvae. After 10:40 h, there was a sharp decline in the number of larvae in the traps 10 to 7 per colony). In the final count of larvae released between the end of the morning excursion and the beginning of the late afternoon excursion, we found 14 colonies with few larvae (0 to 8), although the most active spawner (Colony 5) had released an additional 38 larvae. The mean number of larvae released per colony on July 29 was $54.3 \pm 13.5$ ( $\pm 1 \mathrm{SE}$ ).

On July 30 at $06: 42 \mathrm{~h}$, a check of traps on 14 Callyspongia vaginalis colonies found that during the preceeding night and early morning only 1 larva had been released (by Colony 11) (Table 2). By 08:43 h, the trap on Colony 13 contained 4 larvae. In the $2 \mathrm{~h} 37 \mathrm{~min}$ interval between 08:43 and 11:20 h, 7 sponges released 1 to 15 larvae each, and 2 sponges released more than 200 larvae each. In the $6 \mathrm{~h} 35$ min interval between the

Table 1. Niphates digitalıs. Numbers of larvae counted at each observation period for 15 individual sponge colonies on July 29

\begin{tabular}{|lrrrrrrrrrrrrrrr}
\hline $\begin{array}{l}\text { Observation } \\
\text { period (h) }\end{array}$ & 1 & 2 & 3 & 4 & 5 & 6 & 7 & 8 & 9 & 10 & 11 & 12 & 13 & 14 & 15 \\
\hline $06: 30-06: 40$ & 0 & 0 & 0 & 0 & 2 & 0 & 0 & 0 & 0 & 0 & 0 & 0 & 0 & 0 & 0 \\
$06: 52-07: 13$ & 0 & 2 & 0 & 5 & 0 & 65 & 0 & 0 & 0 & 0 & 0 & 0 & 4 & 0 & 0 \\
$07: 50-10: 40$ & 52 & 28 & 32 & 50 & 150 & 36 & 21 & 36 & 0 & 4 & 93 & 117 & 5 & 2 & 27 \\
$10: 44-11: 09$ & 2 & 2 & 3 & 0 & 3 & 1 & 7 & 1 & 0 & 1 & 1 & 0 & 1 & 0 & 3 \\
$17: 19-17: 44$ & 8 & 1 & 2 & 0 & 38 & 3 & 0 & 1 & 6 & 0 & 0 & 0 & 1 & 0 & 0 \\
\hline
\end{tabular}

Table 2. Callyspongia vaginalis. Numbers of larvae counted at each observation period for 15 individual sponge colonies on July 30

\begin{tabular}{|lrrrrrrrrrrrrrrr}
\hline $\begin{array}{l}\text { Observation } \\
\text { period (h) }\end{array}$ & 1 & 2 & 3 & 4 & 5 & 6 & 7 & 8 & 9 & 10 & 11 & 12 & 13 & 14 & 15 \\
\hline $06: 42-07: 35$ & 0 & 0 & 0 & 0 & 0 & 0 & 0 & 0 & 0 & 0 & 1 & 0 & 0 & 0 & 0 \\
$07: 38-08: 43$ & 0 & 0 & 0 & 0 & 0 & 0 & 0 & 0 & 0 & 0 & 0 & 0 & 4 & 0 & 0 \\
$09: 55-11: 20$ & 2 & 5 & 4 & $>200$ & 0 & 0 & 12 & 0 & 0 & 0 & 15 & 2 & 1 & 0 & $>200$ \\
$16: 53-17: 55$ & 2 & 28 & 2 & 50 & 3 & 0 & 10 & 0 & 0 & 0 & 60 & 7 & 20 & 13 & 0 \\
\hline
\end{tabular}


final morning count and the late afternoon survey, we found 6 traps with 10 to 60 larvae each, 4 traps with 2 to 7 larvae each, and 5 traps with no larvae

Of the 17 captured Niphates digitalis larvae released in the tracking experiment, $13(76 \%)$ remained near the bottom (one of these was attacked by a bicolor damselfish but was rejected), and 8 of these 13 contacted the substrate within $10 \mathrm{~min}$. The other 4 larvae ( $24 \%$ ) moved up beyond the aquanauts' depth ceiling of $15 \mathrm{~m}$.

Discussion. Although daytime spawning has been reported for several broadcasting sponge species under field conditions (Reiswig 1970, Hoppe \& Reichert 1987, Fromont \& Bergquist 1994), no previous study has reported larval release times for brooding sponges in situ. Data on the timing of larval release are critical for understanding a larva's potential vulnerability to predators and environmental stresses. Additionally, if a larva settles soon after its release (e.g. larvae of most colonial tunicates; Svane \& Young 1989), then the timing of larval release can determine the light intensities that larvae experience, which can affect their choice of settlement sites.

Olson (1983) found that the tropical ascidian Didemnum molle releases its larvae near midday and that its larvae settle rapidly. Additionally, newly settled juveniles died within days when exposed to full or UVfiltered sunlight, while shaded juveniles at the same depth $(\sim 2 \mathrm{~m})$ survived significantly longer. Olson thus proposed that the midday release and the photonegative behavior of these larvae at settlement was advantageous because it allowed them to choose photically appropriate, low-light settlement sites at a time when light stress was most intense. Daytime larval release (Tables $1 \& 2$ ) and settlement could similarly be advantageous for shallow-water sponges. In support of this hypothesis, Lindquist (unpubl. data) found that newly settled sponges (Callyspongia vaginalis at $0.5 \mathrm{~m}$. Tedania ignis down to $3 \mathrm{~m}$, and Mycale laxissima down to $10 \mathrm{~m}$ depth) suffered significant mortality after 3 to $5 \mathrm{~d}$ of exposure to natural levels of UV radiation. Sponge larvae typically exhibit traits that would allow them to effectively find photically appropriate microhabitats (i.e. competence to settle soon after release and photonegative behavior at settlement; Bergquist et al. 1970, Wapstra \& van Soest 1987, Meroz \& Ilan 1995, Maldonado \& Young 1996). Selecting settlements sites based on photic cues at night should be difficult, if not impossible.

Conspicuous, undefended larvae released during daylight hours are at great risk from visually acute, day-active fishes. Lindquist \& Hay (1996), however, showed that, despite being large, slow-moving, and physically vulnerable, larvae of both Niphates digitalis and Callyspongia vaginalis are distasteful to common
Caribbean reef fishes. Further assays showed that $C$. vaginalis larvae are chemically defended against fish predation (Lindquist \& Hay 1996). The immunity of these sponge larvae to predation by small planktivorous fishes is likely to be crucial for allowing their release during daylight hours and, particularly important for sessile species, enabling these larvae to utilize the advantages of daytime settlement. In contrast, larvae of brooding corals are readily consumed by fishes but released at night when they are less apparent to fishes (Lindquist \& Hay 1996). The results of this study are the first to rigorously demonstrate daytime release of sponge larvae known to be distasteful to potential predators. These data support a general co-occurrence of daytime spawning of conspicuous, short-lived larvae and larval distastefulness that previously had been documented only among colonial ascidians in the tropics (Young \& Bingham 1987, Lindquist et al. 1992). These characterisitcs may also co-occur among some bryozoans and hydroids (Lindquist \& Hay 1996).

Acknowledgements. Support was provided by the National Undersea Research Center (NURC) at the University of North Carolina at Wilmington under NOAA grant number NA36RU0060 to N.L. Comments by Mark Hay, Stephan Bullard, Mike Deal, Jay Stachowicz and 3 anonymous reviewers improved the manuscript. The NURC staff in Florida were exceptionally helpful in expediting this investigation. Greg McFall, Brian Chanas, and Dave Swearengen assisted with some field feeding assays.

\section{LITERATURE CITED}

Amano S (1986) Larval release in response to a light signal by the intertidal sponge Hahchondria panicea. Biol Bull (Woods Hole) 171:371-378

Amano S (1988) Morning release of larvae controlled by the light in an intertidal slonge, Callyspongra rumosa. Biol. Bull (Woods Hole) 175:181-184

Babcock RC, Bull GD, Harrison PL, Heyward AJ, Oliver JK, Wallace CC, Willis BL (1986) Synchronous spawning of 105 scleractinian coral species on the Great Barrier Reef. Mar B1ol 90:379-394

Bergquist PR, Sinclair ME. Hogg JJ (1970) Adaptatıon to intertidal existence: reproductjve cycles and larval behav10ur in Demospongiae. Symp Zool Soc Lond 25:247-271

Bingham BL, Young CNI (1991) Larval behavior of the ascudian Ectemascidia turbinata Herdman: an in situ expenmental study of the effects of swimming on dispersal $J$ Exp Mar Biol Ecol 145:189-204

Davis AD, Butler AL (1989) Direct observations of larval dispersal in the colonial ascidian Podoclavella moluccensis Sluiter: evidence for closed populations. J Exp Mar Biol Ecol 127:189-203

Fromont J (1994) Reproductive development and timing of tropical sponges (Order Haposclerida) from the (ireat Barrier Reef, Australia. Coral Reefs 13:127-133

Fromont J, Bergquist PR (1994) Reproductive biology of three sponge species of the genus Xestospongia (Ponfera: Demospongiae: Petrosidae) from the Great Barner Reef Coral Reefs 13:119-126 
Grosberg RK, Quinn JF (1986) The genetic control and consequences of kin recognition by the larvae of a colonial marine invertebrate. Nature 322:456-459

Hoppe WF, Reichert MJM (1987) Predictable annual mass release of gametes by the coral reef sponge Neofibularia nolitangere (Porifera: Demospongia). Mar Biol 94:277-285

llan M, Loya L (1988) Reproduction and settlement of the coral reef sponge Niphates sp. (Red Sea). Proc 6th Int Coral Reef Symp 2:745-749

Ilan M, Loya L (1990) Sexual reproduction and settlement of the coral reef sponge Chalinula sp. from the Red Sea. Mar Biol 105:25-31

Keough MJ, Downes BJ (1982) Recruitment of marıne ınvertebrates: the role of active larval choice and early mortality. Oecologia 54:348-352

Lindquist N (1996) Palatability of invertebrate larvae to corals and anemones. Mar Biol 126:745-755

Lindquist N, Hay ME (1996) Palatability and chemical defense of marine invertebrate larvae. Ecol Monogr 66: $431-449$

Lindquist N, Hay ME, Fenical W (1992) Defense of ascidians and their conspicuous larvae; adults vs. larval chemical defenses. Ecol Monogr 62:547-568

Maldonado M, Young CM (1996) Effects of physical factors on larval behavior, settlement and recruitment of four tropical demosponges. Mar Ecol Prog Ser 138:169-180

Meroz E, Ilan M (1995) Life history characteristics of a coral reef sponge. Mar Biol 124:443-451.

Morgan SG (1995a) Life and death in the plankton: larval mortality and adaptation. In: McEdwards L (ed) Ecology of marine invertebrate larvae. CRC Press, Boca Raton, FL, p 279-321

Morgan SG (1995b) Timing of larval release. In: McEdwards $\mathrm{L}$ (ed) Ecology of marine invertebrate larvae. CRC Press, Boca Raton, FL, p 157-191

Olson RR (1983) Ascidıan-prochloron symbiosis: the role of larval photoadaptations in midday larval release and settlement. Biol Bull (Woods Hole) 165:221-240

Olson RR, McPherson R (1987) Potential vs. realized larval dispersal: fish predation on larvae of the ascidian Lisso-

This note was presented by Joseph Pawlik (Senior Editorial Advisor), Wilmington, North Carolina, USA clinum patellä (Gottschaldt). J Exp Mar Biol Ecol 110: 245-256

Reiswig HM (1970) Porifera: sudden sperm release by tropical Demospongiae. Science 170:538-539

Rumrill SS (1990) Natural mortality of marine invertebrate larvae. Ophelia 32:163-198

Stoner DS (1990) Recruitment of a tropical colonial ascidian; relative importance of pre-settlement vs. post-settlement processes. Ecology 71:1682-1690

Strathmann RR (1985) Feeding and nonfeeding larval development in the life-history evolution in marine invertebrates. Annu Rev Ecol Syst 16:339-361

Svane I, Young CM (1989) The ecology and behaviour of ascidian larvae. In: Barnes $M$ (ed) Oceanography and marine biology, Vol 27. Aberdeen University Press, Aberdeen, p 45-90

van Duyl FC, Bak RPM, Sybesma J (1981) The ecology of the tropical compound ascidian Trididemnum solidum. I. Reproductive strategy and larval behaviour. Mar Ecol Prog Ser 6:35-42

Wapstra M, van Soest RMW (1987) Sexual reproduction, larval morphology, and behaviour in Demosponges from the southwest of the Netherlands. In: Vacelet J, Boury-Esnault $N$ (eds) Taxonomy of Porifera. Springer-Verlag, Berlin, p 281-307

Woollacott RM (1993) Structure and swimming behavior of the larva of Haliclona tubifera (Porifera: Demospongiae). J Morphol 218:301-321

Young CM, Bingham BL (1987) Chemical defense and aposematic coloration in larvae of the ascidian Ectemascidia turbinata. Mar Biol 96:539-544

Young CM. Chia FS (1984) Microhabitat-associated varability in survival and growth of subtidal solitary ascidians during the first 21 days after settlement. Mar Biol 81:61-68

Young CM, Chia FS (1989) Abundance and distribution of pelagic larvae as influenced by predation, behaviour, and hydrographic factors. In: Giese C, Pearse JS, Pearse VB (eds) Reproduction of marine invertebrates, Vol 9. Blackwell Scientific Publications, Palo Alto, CA, and The Boxwood Press, Pacific Grove, CA, p 385-463

Manuscript received: May 2, 1997

Revised version accepted: June 30, 1997 